\title{
Combining mechanical foaming and thermally induced phase separation to generate chitosan scaffolds for soft tissue engineering
}

\author{
DP. Biswas, PA. Tran, C. Tallon \& AJ. O'Connor
}

To cite this article: DP. Biswas, PA. Tran, C. Tallon \& AJ. O'Connor (2016): Combining mechanical foaming and thermally induced phase separation to generate chitosan scaffolds for soft tissue engineering, Journal of Biomaterials Science, Polymer Edition, DOI: 10.1080/09205063.2016.1262164

To link to this article: http://dx.doi.org/10.1080/09205063.2016.1262164

Accepted author version posted online: 23

Nov 2016.

Submit your article to this journal $₫$

Q

View related articles 두

View Crossmark data $₫$ 
Publisher: Taylor \& Francis

Journal: Journal of Biomaterials Science, Polymer Edition

DOI: http://dx.doi.org/10.1080/09205063.2016.1262164

Combining mechanical foaming and thermally induced phase separation to generate chitosan scaffolds for soft tissue engineering

DP. Biswas ${ }^{\mathrm{a}}$, PA. Tran ${ }^{\mathrm{a}, \mathrm{b}}$, C.Tallon ${ }^{\mathrm{a}, \mathrm{c}, \mathrm{d}}$ and AJ. O'Connor ${ }^{\mathrm{a}^{*}}$

a Department of Chemical and Biomolecular Engineering, Particulate Fluids Processing Centre, The University of Melbourne, VIC 3010, Australia

${ }^{b}$ The Institute of Health and Biomedical Innovation, Queensland University of Technology, 60 Musk Ave, Kelvin Grove QLD 4059, Australia

${ }^{c}$ Defence Materials Technology Center (DMTC), Hawthorn 3122 VIC, Australia ${ }^{\mathrm{d}}$ Department of Materials Science and Engineering, Virginia Polytechnic Institute and State University, Blacksburg, 24061, VA, United States.

*corresponding author: a.oconnor@unimelb.edu.au 


\section{Combining mechanical foaming and thermally induced phase separation to generate chitosan scaffolds for soft tissue engineering}

In this paper, a novel foaming methodology consisting of turbulent mixing and thermally induced phase separation (TIPS) was used to generate scaffolds for tissue engineering. Air bubbles were mechanically introduced into a chitosan solution which forms the continuous polymer/liquid phase in the foam created. The air bubbles entrained in the foam act as a template for the macroporous architecture of the final scaffolds. Wet foams were crosslinked via glutaraldehyde and frozen at $-20^{\circ} \mathrm{C}$ to induce TIPS in order to limit film drainage, bubble coalescence and Ostwald ripening. The effects of production parameters, including mixing speed, surfactant concentration and chitosan concentration, on foaming are explored. Using this method, hydrogel scaffolds were successfully produced with up to $80 \%$ porosity, ayerage pore sizes of $120 \mu \mathrm{m}$ and readily tuneable compressive modulus in the range of 2.6 to $25 \mathrm{kPa}$ relevant to soft tissue engineering applications. These scaffolds supported 3T3 fibroblast cell proliferation and penetration and therefore show significant potential for application in soft tissue engineering.

Keywords: Foaming, TIPS, tissue engineering, scaffolds, chitosan, PVA

\section{Introduction}

In tissue engineering biomaterial scaffolds are routinely implemented as a foundation for various strategies to promote tissue formation (1). Due to the multitude of functions, complex composition and the dynamic state of native extracellular matrix (ECM) it is difficult to engineer scaffolds that can completely recapitulate all the properties of native $\operatorname{ECM}(2)$. However current understanding of tissue engineering principles has identified key material properties that are required for development of a scaffold that can partially mimic the functions of the ECM. These include:

1) Utilisation of materials that are biocompatible towards endogenous cells and tissues which minimize the likelihood of foreign body reactions (3);

2) Control of scaffold architecture in terms of pore sizes, porosity and interconnectivity to enhance cell proliferation, vascularisation and mass transfer of oxygen and nutrients (4);

3) Suitable bioactivity of the scaffold in terms of structural similarity to ECM, biodegradability, incorporation and delivery of growth factors and/or cell adhesive ligands which can accelerate cell proliferation and tissue ingrowth (5);

4) Scaffolds should possess appropriate shape and similar mechanical properties to the tissue they seek to repair as cells are known to be sensitive to their mechanical environment $(6,7)$.

For soft tissue engineering, hydrogel scaffolds are generally recognized as suitable potential analogues for the ECM (8). A large variety of polymers of both synthetic and natural origin have been utilized to develop hydrogel scaffolds, however natural polymers often exhibit enhanced bioactivity and biocompatibility due to their structural similarity towards native ECM (9). For example chitosan, a derivative of chitin, has a polymer backbone similar to the glycosaminoglycans found in the ECM (10). Furthermore chitin is a large waste product in the 
fisheries industries (11) so the cost of manufacturing chitosan on a large scale would be relatively low. Also the presence of amine residues on the polymer backbone makes chitosan amenable to a large number of chemical modifications (12). Chitosan on its own, chemically modified or blended with other materials has been investigated for a large number of tissue engineering applications including wound healing $(13,14)$, skin tissue $(10,15)$, bone tissue $(16$, $17)$, cartilage tissue $(18,19)$, neural tissue $(20,21)$, corneal tissue $(22,23)$ and liver tissue $(24)$ regeneration. Due to its biological interactions and gel forming properties chitosan was chosen as the main polymer backbone for our hydrogel system.

A large number of scaffold fabrication techniques can be utilized to control the pore architecture of scaffolds, e.g., porogen leaching $(25,26), \operatorname{TIPS}(27,28)$ and 3D printing(29). However, there is still a need for simple, inexpensive techniques that can control important structural aspects of tissue engineering scaffolds such as porosity, pore size and interconnectivity in the required ranges. These important properties are key to cell migration, vascularisation and mass transport in the scaffolds upon implantation. Therefore, in this study we introduce a facile combined TIPS and gas foaming technique that can be utilized to create macropores in the hundreds of microns range into chitosan scaffolds. This method avoids the relatively expensive pressurized compressed gases and pressure vessels $(30-32)$, in situ reactions $(33,34)$ and energy intensive freeze drying steps $(35,36)$ used in the majority of scaffold production methods involving gas foaming previously.

Foam stability and inherent porous macrostructure are critical for many applications in food, polymer and ceramics processing. Using foams as templates for the production of macroporous structures is attractive as the processes can be simple and relatively low cost to scale up. Additionally, the foam properties (e.g., porosity, pore size, interconnectivity, mechanics) can be tuned by controlling the production processing conditions (e.g., mixing hydrodynamics and time, surfactant type and concentration) (37-39). The porosity and interconnectivity of bioactive glass scaffolds for bone tissue engineering produced via foaming were shown to be affected by the choice of surfactant, surfactant concentration and presence of electrolytes (41)(42). Therefore in this study, foams were produced as tuneable templates for macropores in hydrogel scaffolds.

Air bubbles were incorporated into a chitosan-based polymeric system by mechanical mixing to act as porogens in the final hydrogel foam. Freezing the foams allowed thermally induced phase separation, rapid stabilisation of the foam structures and chemical cross linking to occur. This helped to prevent the air bubbles coalescing and improved the interconnectivity of the foams. Poly vinyl alcohol (PVA) was used as a surfactant to stabilise the foams due to its water solubility and cytocompatibility towards mammalian cells (44). The major benefit of this technique is that it uses simple inexpensive mechanisms to incorporate air to form tuneable macroporous foams, avoiding the use of toxic organic solvents for porogen removal and issues with residual porogens or solvents which can be detrimental towards cells are avoided. The manipulation of parameters including the mixing speed, surfactant concentration, and chitosan concentration are shown to control the overall porosity, pore size and mechanical properties of the scaffolds, which are important for applications in tissue engineering.

\section{Materials \& Methods}




\subsection{Materials}

Medium molecular weight chitosan (180-310 kDa, degree of deacetylation $85 \%$ ) and poly vinyl alcohol (10,000 Da, 80\% hydrolysed) (Sigma Aldrich, Australia) were used for foamed hydrogel formulation. All solutions were made with ultrapure water purified to a resistivity of $18.2 \mathrm{M} \Omega$ in a Millipore water filtration system (Millipore, Victoria, Australia). Acetic acid (0.88M) was used to dissolve both chitosan and PVA. Glutaraldehyde (Thermofischer Scientific, Australia) was utilized for covalently crosslinking the chitosan and PVA during scaffold formation. Sodium hydroxide (Chem Supply, Victoria, Australia) solution (3M) was used to neutralize foamed scaffolds. Phosphate buffered saline and glycine (Sigma Aldrich, NSW, Australia) were used to wash foamed scaffolds to remove contaminants and cap any unreacted glutaraldehyde, respectively.

NIH 3 T3 fibroblasts (ATCC, Virginia, USA) were grown in Dulbecco's Modified Eagle's Medium (DMEM, Sigma Aldrich, Australia) supplemented with $10 \%$ fetal bovine serum (Scientifix Life, Victoria, Australia), 4mM glutamine and $100 \mathrm{U} / \mathrm{ml}$ penicillin-streptomycin (Sigma Aldrich, NSW, Australia). Cells were detached from culture plates using $0.25 \%$ Trypsin (Gibco Life Technologies, Auckland New Zealand). Cell proliferation on scaffolds was monitored using Alamar Blue Assay, 4,6-diamidino-2-phenylindole (DAPI; Sigma Aldrich, NSW, Australia) and CellTracker ${ }^{\mathrm{TM}}$ Deep Red Dye (ab 138894; ABcam, Victoria, Australia). The Alamar Blue Assay was prepared by dissolving Resazurin dye (Sigma Aldrich, NSW, Australia) in phosphate buffered saline (PBS) (Sigma Aldrich, NSW, Australia) to a concentration of $440 \mu \mathrm{M}$. The solution was sterilized using a $0.22 \mu \mathrm{m}$ syringe filter (Millipore, Victoria, Australia).

\subsection{Foam production}

Various weights of chitosan were dissolved in $0.88 \mathrm{M}$ acetic acid and mixed with the required concentrations of PVA (also dissolved in $0.88 \mathrm{M}$ acetic acid) in $28 \mathrm{ml}$ polypropylene vials (LabTek, Queensland, Australia), to reach the desired final concentrations of chitosan and PVA, with the final total volume of the mixtures fixed at $5 \mathrm{ml}$. Air bubbles were introduced into the chitosan and PVA solutions using a custom built four loop blade impeller made of stainless steel (Figure 1) attached to a mixer drive unit (IKA 20) (Thermofischer Scientific, Australia).

The impeller was lowered into the chitosan PVA solution with a clearance of $2 \mathrm{~mm}$ from the base of the vial. The speed of the mixer was varied to introduce different volumes of air during the mixing process. The solution was then foamed for the required time and the foamed height was measured. To determine the overall volume of air introduced, foams were centrifuged in an Allegra $^{\mathrm{TM}}$ X-15R Centrifuge (Beckman Coulter, Victoria, Australia) at $4000 \mathrm{rpm}$ for 15 minutes to destabilize the bubbles and obtain the height and volume of the solution after the bubbles collapsed and thus estimate the volume of air entrained within the foams. The foam production conditions of mixing speed (600-2000 rpm) and time (0-10 min), PVA concentration (0-30 $\mathrm{mg} / \mathrm{ml}$ ) and chitosan concentration $(5-50 \mathrm{mg} / \mathrm{ml})$ were each varied whilst holding the other parameters constant to establish the optimal conditions for foam formation. Table 1 shows the parameters varied and kept constant during the foam production. 


\subsection{Fabrication of solidified hydrogel foams}

Once the desired foam formation conditions were determined as described above, scaffolds were produced using a mixing speed of $1500 \mathrm{rpm}$ for 5 minutes (Figure 2). To convert the gas-liquid foams into scaffolds, $142 \mu \mathrm{l}$ of $2.5 \mathrm{w} / \mathrm{w} \%$ glutaraldehyde (GA) solution was added to the foams. The aldehyde groups on GA react with both amine and hydroxyl groups present on chitosan and hydroxyl groups on PVA, covalently linking the polymer chains, and reducing the possibility of foam destabilization due to bubble coalescence and coarsening. GA was introduced towards the end of foaming step to avoid crosslinking the polymers before the foam was fully formed, which would restrict the amounts of air entrained. The foam was mixed for a further minute at 1500 rpm to distribute the GA. Then the whole vessel containing the foam was quickly transferred to a recirculating water bath (Alpha Ra 12, Lauda, Victoria, Australia) containing $50 \mathrm{v} / \mathrm{v} \%$ water and ethylene glycol (Ajax Finechem, Victoria, Australia), set at $-20^{\circ} \mathrm{C}$ to allow foam gelation and TIPS of the polymer solution to occur. After 24 hours of incubation, the scaffolds were removed from the vials and sectioned into 1-2 mm slices using a scalpel blade and custom made cutting guide. Scaffolds were washed in excess $3 \mathrm{M} \mathrm{NaOH}$ on an orbital shaker (ZHICHENG, All Lab Scientific, Victoria, Australia) at $120 \mathrm{rpm}$ for an hour to neutralize the acetic acid. The scaffolds were then washed in excess $0.1 \mathrm{M}$ glycine for a further 1 hour to cap any unreacted GA, rinsed with water and then stored in PBS for up to 3 days at $4^{\circ} \mathrm{C}$ until characterisation or use.

\subsection{Scaffold pore characterization}

Thin scaffold slices (1-2 mm) were imaged using a confocal laser scanning microscope (Leica DMIRE2) with a 10x objective lens. Scaffolds were illuminated with a laser at $458 \mathrm{~nm}$ and the emission acquired at 470-520 nm. Image analysis software Fiji and ImageJ (NIH, USA) were used to analyse at least 100 pores for each set of scaffold synthesis conditions. A grid overlay was used on images, all at the same magnification, to randomize the selection of pores for measurement (43) and avoid potential operator bias in pore size measurements. The grid contained nine equally spaced horizontal lines and pores crossed by these lines were selected to be measured. The pore sizes were estimated by determining the Feret's diameter for each pore selected by drawing circles to fit each pore in ImageJ. The pixel to length ratio was embedded automatically on each confocal micrograph via the microscope software (Leica DM IRE2, Leica Microsystems).

\subsection{Swelling ratios and porosities}

The water absorption capacity of hydrogel scaffolds is important for allowing diffusion of nutrients and exchange of metabolic wastes and $\mathrm{O}_{2}$, as well as affecting the mechanical properties of the scaffolds. The extent of water absorption was characterized by the swelling ratio:

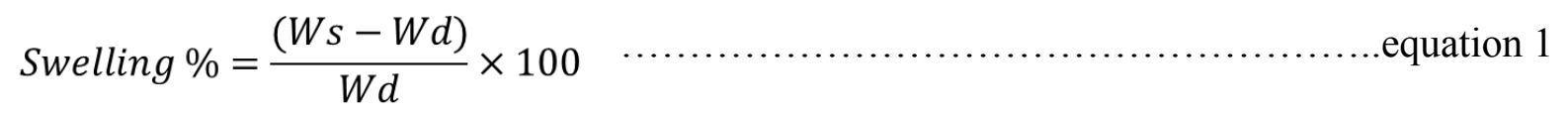

where $W_{d}$ is the dry weight of the scaffold and $W_{s}$ is the swollen weight. Scaffolds were dried in an oven at $100^{\circ} \mathrm{C}$ for 24 hours before the dry weights measured. Next, the scaffolds were 
incubated in PBS at $37^{\circ} \mathrm{C}$ for 24 hours. A tissue (Kimwipe, Kimberly-Clark Professional, Australia) was used to remove excess fluid from the surface of the scaffold following which its wet weight was measured. Four repeats for each condition were performed.

The porosities of the scaffolds were estimated by squeezing the swollen scaffolds to displace the liquid from their pores and comparing their weights before $\left(W_{s}\right)$ and after $\left(W_{s q}\right)$ this process. This method provides an approximate measure of the scaffold porosity as it removes liquid from the pores without using a drying step, which would also remove water from the swollen scaffold walls (31). The total volume of macropores and the porosity of the scaffolds were thus estimated using equation $2(45,46)$. The average of four repeats on different scaffolds for each condition was reported.

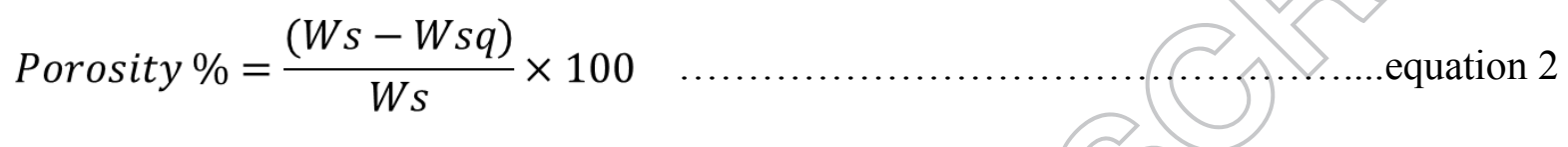

\subsection{Solution viscosity measurements}

The viscosities of mixtures of chitosan and PVA were measured using a controlled stress AR-G2 rheometer (TA instruments, Rydalmere, Australia). The measurement configuration used was parallel plate (40 mm diameter) with $1 \mathrm{~mm}$ gap between the plates. The rheological behaviour of the mixtures was determined by controlled rate measurements in the linear viscoelastic region. The shear rates were varied from $0.01 \mathrm{~s}^{-1}$ to $1000 \mathrm{~s}^{-1}$ over a 10 minute period at $25^{\circ} \mathrm{C}$. Stress and viscosity were recorded for each shear rate.

\subsection{Mechanical testing of scaffolds}

Compressive mechanical properties of foamed scaffolds made with various PVA and chitosan concentrations were measured with an Instron Microtester 5848 (Instron, Bayswater, Australia). Swollen scaffolds were placed in a petri dish containing PBS during measurement to improve the reproducibility of the results and prevent drying of the scaffolds which would affect the measurements. A 5 N load cell with a crosshead speed of $2 \mathrm{~mm} / \mathrm{min}$ (47) and compressive strain of $30 \%$ (48) was applied to each scaffold. The compressive modulus was calculated from the linear range of the stress-strain curve between 10-20\% strain (47). Mean values were calculated from three different scaffolds per condition.

\subsection{Fibroblast culture on scaffolds}

NIH embryonic mouse 3T3 fibroblasts (passage 6-10) were suspended in DMEM supplemented with $1 \%$ penicillin-streptomycin, $1 \%$ L-glutamine and 10\% fetal bovine serum (FBS). Cells were incubated at $37^{\circ} \mathrm{C}$ in $5 \% \mathrm{CO}_{2}$. For cell proliferation studies scaffolds formulated from $30 \mathrm{mg} / \mathrm{ml}$ chitosan and $20 \mathrm{mg} / \mathrm{ml}$ PVA (mixing speed $1500 \mathrm{rpm}$, foaming time $6 \mathrm{~min}$, GA crosslinked) were cut into slices of approximately $2 \mathrm{~mm}$ height using a custom-made cutting guide. Discs of 5 $\mathrm{mm}$ diameter were then cut from the central region of these slices using a circular hole punch. Scaffolds were soaked in $80 \%$ ethanol overnight followed by washing in sterile PBS several 
times. Scaffolds were then soaked in complete DMEM for 1 hour to allow the scaffold pore walls and pores to be saturated with DMEM and avoid potential depletion of media components during cell culture due to surface adsorption. Scaffolds were then transferred to clear 96 well plates $\left(\right.$ Costar $^{\circledR}$, Sigma Aldrich, NSW, Australia). 3T3 cells were added to each well containing the scaffolds $(5000$ cells in $100 \mu \mathrm{l})$. For the positive control, 5000 cells in $100 \mu \mathrm{l}$ were transferred to empty wells, and scaffolds without cells were incubated with $100 \mu 1$ of supplemented DMEM as a negative control. Each well was then topped up with another $100 \mu 1$ of supplemented DMEM. Proliferation of cells was quantified using the Alamar Blue Assay (49). Briefly Alamar Blue contains a Resazurin dye which can be reduced to a fluorogenic compound by metabolically active cells (50). The concentration of dye converted is directly proportional to the number of cells present. The dye $(20 \mu \mathrm{l})$ was added aseptically to each well and incubated for $4 \mathrm{~h}$ at $37^{\circ} \mathrm{C}$. Aliquots of $100 \mu \mathrm{l}$ of the dye plus DMEM mixture from each well were transferred to white 96 well plates (Corning ${ }^{\circledR}$, Sigma Aldrich, NSW, Australia). Fluorescence intensities were measured using a fluorescence plate reader (infinite 200 Pro, Tecan, Switzerland) with excitation and emission wavelengths of $545 \mathrm{~nm}$ and $590 \mathrm{~nm}$, respectively. The relevant background fluorescence intensities (with or without scaffolds present) were subtracted to obtain the final values. The remainder of the dye and DMEM mixture was pipetted out to avoid oversaturation of the resofurin product during continued culture, which can lead to saturation in fluorescence intensities. Fresh complete DMEM was added to replenish the cells and further incubated for 24 hours at $37^{\circ} \mathrm{C}$ until the next time point for measurements. Data were recorded at 24,48 and 72 hours using four replicates at each condition.

Confocal microscopy was used to visualize fibroblasts grown on and inside the scaffolds. Scaffold discs were prepared as above but the scaffolds were blotted with sterile gauze to partially remove DMEM from the scaffold walls and pores before being transferred to sterile clear 96 well plates. These scaffolds were then swollen with a cell suspension containing 100,000 cells in $50 \mu \mathrm{l}$ of media. Scaffolds were left to incubate for 2 hours to allow cell attachment to the scaffold, following which a further $150 \mu \mathrm{l}$ of DMEM was added to each well. This facilitates cell penetration and attachment in the scaffolds using capillary action to carry the suspension into the scaffold as it swells (51). Scaffolds loaded with cells were incubated for 3 days with the culture media being changed every 24 hours. Following this, scaffolds were sectioned in a sterile biosafety cabinet with sterile scalpel blades, revealing the cross-section and surface of the scaffolds. A live-dead assay, CellTracker ${ }^{\mathrm{TM}}$ Deep Red Dye, was diluted 100 times in PBS and $100 \mu 1$ of this dye solution was added to each well containing the sectioned scaffolds and incubated at $37^{\circ} \mathrm{C}$ for one hour. Scaffolds were then washed with sterile PBS following which $100 \mu$ of DAPI dye diluted 1000 times in PBS was added to each well for 30 minutes' incubation at $37^{\circ} \mathrm{C}$. Scaffolds were washed in PBS and imaged by confocal microscopy as above.

\subsection{Statistical analysis:}

Statistical analyses were carried out using one way analysis of variance (ANOVA) with post-hoc Tukey test, using Minitab 16 software (Pennsylvania, US). Data (mean \pm standard deviation) were reported as statistically significant if their $p$ values were $<0.05$. 


\section{Results and discussion}

\subsection{Control parameters for the foaming process}

Key parameters controlling the foaming process for the chitosan/PVA system were first investigated. The surfactant concentration, mixing speed, time of foaming and concentration of chitosan were varied to assess their effects and identify suitable ranges for foam formation (Figure 3).

The presence of a surface active agent is crucial for the formation of stable foams in this system, as shown in Figure 3A. When the PVA concentration was increased, the volume of air incorporated within the system increased up to concentrations of $10 \mathrm{mg} / \mathrm{ml} \mathrm{PVA}$, beyond which there was no significant change. This could be an indication that the critical micelle concentration (CMC) of PVA in this system has been reached, as suggested in other foam surfactant systems (52-54). Instead of adsorbing to the new surfaces created during mixing, the surfactants self-assemble and stay in the solution phase, so they are not available to stabilize any further incorporation of air into the system. Kim et al. showed that the CMC of PVA (9000$10000 \mathrm{MW}$ ) in neutral solution was around $1.4 \mathrm{mg} / \mathrm{ml}(55)$. This is considerably lower than the CMC suggested in our system; however, this system has other factors, namely the presence of chitosan, higher ionic strength and lower $\mathrm{pH}$ that could affect the CMC.

Mixing speed is important for controlling the amount of entrapped air within the foam. The volume of air entrained increased when the mixing speeds were varied from $600 \mathrm{rpm}$ up to 1200 $\mathrm{rpm}$, as seen in Figure 3B. Foams were not observed at mixing speeds below $400 \mathrm{rpm}$, suggesting that there was a critical mixing speed below which foaming was not possible for this system. In addition to air entrainment from the air-liquid interface, it has been suggested that in turbulent mixing regimes, as the ones used here, the rotation of the impeller results in low pressure cavities at the impeller blade-solution interface, which are subsequently sheared off into bubbles by the rotation of the impeller $(56,57)$. The surfactant and viscous properties of PVA and chitosan are expected to help stabilize the bubbles, but shear-induced breakup may also occur. At mixing speeds greater than $1200 \mathrm{rpm}$, no more air was entrained into the system. This suggests that most of the surfactant molecules have been used in the system to stabilize bubbles. Figure $3 \mathrm{C}$ shows the effect of mixing time on the production of these foams from 15 seconds up to 10 minutes while keeping the mixing speed and concentrations of chitosan and PVA constant. After 2 minutes of foaming no further significant change in foam volume was observed. Thus for subsequent tests, a foaming time of 5 minutes was selected.

The concentration of chitosan has a significant effect on the volume of air entrained within the foam, with a maximum occurring around $25 \mathrm{mg} / \mathrm{ml}$ (figure 3D). At $5 \mathrm{mg} / \mathrm{ml}$ chitosan, no foam was observed in the presence of $20 \mathrm{mg} / \mathrm{ml}$ PVA. The liquid phase viscosity along with a decrease in interfacial surface tension caused by the surfactants in the solution are important parameters for foam stabilization $(43,58)$. The solution viscosity is responsible for slowing down film drainage between bubbles, thereby aiding in the stabilization of foams (59). As shown in Figure 4, increasing the concentration of chitosan led to increases in the solution viscosity. The low viscosities observed at $5 \mathrm{mg} / \mathrm{ml}$ chitosan correspond to no air being entrained into the 
foam, as seen in Figure 3C. The bubbles were not stabilized within the system, and the liquid phase between bubbles drained out relatively rapidly. When the concentration of chitosan was 25 $\mathrm{mg} / \mathrm{ml}$, the viscosity of the solution was optimal for air bubble stability in the presence of PVA. However with further increases in viscosity, the air entrapment process became significantly less effective, probably due to the larger resistance to shear $(59,60)$.

\subsection{Synthesis of chitosan/PVA scaffolds}

Wet foams generated from the foaming process are thermodynamically and mechanically unstable and unsuitable for tissue engineering applications. Therefore, the wet foams required further processing to be transformed into solid form. In ceramics processing, wet foams can be solidified using gelcasting to lock the foam structures into a piece which can be handled and lightly machined (43). A similar approach was adopted in this case. After the foaming step, a small volume of GA as a crosslinker was introduced into the foam and mixed further for 1 minute at $1500 \mathrm{rpm}$, after which the wet foams in their containers were transferred into a water bath (containing $50 \mathrm{v} / \mathrm{v} \%$ ethylene glycol and water) at $-20^{\circ} \mathrm{C}$ for 24 hours to allow cryogelation to occur. This resulted in the solidification of the foams, preserving their bubble structure and potentially also forming an additional level of porosity at a smaller length scale due to the phase separation of the solution into a polymer rich and a polymer poor phase during freezing $(61,62)$. The chitosan/PVA and GA solution becomes localized in the thin films separating the bubbles during foaming and the GA crosslinks the polymer, further stabilizing the foam structure.

The crosslinking reaction is promoted by cryo-concentration, which occurs due to the phase separation as the sample is chilled (46). The crosslinking step is crucial since without its use, the wet foam collapses when it is thawed. Colour changes of the solidified foams from white to a faint yellowish colour were a direct result of GA crosslinking the chitosan polymers. Formation of imine bonds due to the reaction between aldehyde side chains of GA and amine groups present on chitosan leads to the yellow colour $(63,64)$. The transformation from a liquid to a wet foam and ultimately into a foamed hydrogel scaffold is shown in Figure 5. Further washing in sodium hydroxide neutralizes acetic acid $(65,66)$ and a washing step in $0.1 \mathrm{M}$ glycine ensured that any unreacted GA groups were capped to prevent a cytotoxic effect on living cells $(67,68)$.

\subsection{Effect of mixing speed, surfactant and chitosan concentrations on the scaffold pore sizes and morphologies}

Pore size, porosity and interconnectivity of tissue engineering scaffolds are important for cell infiltration, vascularization, oxygen diffusion, nutrient and waste transport and mechanical properties of scaffolds (69). Figure 6 shows typical confocal micrographs obtained for a range of PVA concentrations, at a fixed chitosan concentration and mixing speed, from the central region of the scaffolds. Air entrained within the scaffolds via foaming ultimately resulted in spherical bubble-like pores within the scaffolds. The presence of smaller openings between the pores suggested that these scaffolds have interconnectivity. From the micrographs in Figure 6 (A-D) it can also be seen that the pore sizes were quite polydisperse, with average pore sizes around 120 $\mu \mathrm{m}$. Irregularly shaped pores that typically arise from TIPS were not observed within the crosssections of these scaffolds. However typical TIPS morphology pores were present on the outer 
surfaces of these scaffolds (not shown here). These irregular shaped pores only persisted for less than a $1 \mathrm{~mm}$ into the foamed scaffolds.

Thus the majority of the pores were of a spherical morphology, as seen in Figure 6. This suggests that the air bubbles along with the thin liquid films between the bubbles provided a large physical impediment to the ice crystal growth in TIPS (70), limiting their growth inside the foamed scaffolds. The polydisperse nature of the pores observed in these foams are most likely due to the random eddies and complex tortuous flow conditions present during turbulent mixing leading to highly random formation and breakage of bubbles, resulting in a wide distribution of bubble sizes (71). While bubble coalescence may also be a factor involved in the wide bubble size distribution, the presence of surfactants and rapid freezing during foam gelation ensure a relatively quick locking of the structure, minimizing film drainage and coalescence at the selected conditions.

The mean pore sizes of the scaffolds varied from around 120 to $170 \mu \mathrm{m}$ as the PVA concentration was changed (Figure 7A). Somewhat larger mean sizes were found at intermediate PVA concentrations (10 and $15 \mathrm{mg} / \mathrm{ml})$ for the selected mixing conditions $(1500 \mathrm{rpm}, 25 \mathrm{mg} / \mathrm{ml}$ chitosan and 6 min. foaming) than at lower or higher concentrations $(p<0.05)$, although their ranges did still overlap. The mixing speed used to create the foams also showed a weak effect on the mean pore sizes (Figure 7B), with the highest mixing speed resulting in slightly smaller pores than the slowest speed at the conditions tested.

The chitosan concentration also had a significant effect on the mean pore sizes (Figure 7C) with higher concentrations $(40-50 \mathrm{mg} / \mathrm{ml})$ resulting in smaller pores compared to lower concentrations $(25-30 \mathrm{mg} / \mathrm{ml})$. This is consistent with the larger viscous forces present at higher chitosan concentrations (Figure 4), which limit air entrainment during foaming (Figure 3D) and bubble growth, thus limiting the resultant pore sizes. Again, although the differences were shown to be statistically significant by ANOVA, the distribution of sizes at each concentration was wide and their ranges overlapped. Thus scaffolds with similar mean pore sizes of more than $100 \mu \mathrm{m}$, as desired for vascularisation in tissue engineering, can be produced under a broad range of production conditions.

\subsection{Swelling properties and porosities of foamed scaffolds.}

Although the pore sizes did not change dramatically, changing the chitosan concentration had a much more significant effect on the amount of air entrapped in the foams and thus on their porosities and swelling ratios (Figure 8). There was a gradual decrease in porosity as the chitosan concentration increased. A similar trend was observed with the swelling ratio, which decreased from approximately $1500 \%$ to $440 \%$ for chitosan concentrations of 25 to $50 \mathrm{mg} / \mathrm{ml}$. This is consistent with the measured solution viscosities, showing that at higher concentrations of chitosan, the higher viscosities made it more difficult to entrain air within the scaffolds (Figures 3D and 4). Nonetheless, the swelling ratios and porosities of the scaffolds were quite large and so could be beneficial for supporting cell growth.

\subsection{Mechanical properties of scaffolds.}


The mechanical properties of the foamed scaffolds could be modulated readily by changing the chitosan concentration. As shown in Figure 9, an increase in chitosan concentration led to a significant increase in compressive modulus. It was shown (Figure 3D) that increasing chitosan concentration led to a decreasing volume of air being incorporated in the foams, which would result in denser scaffolds, accounting for the increase in compressive modulus observed. The scaffolds have relatively low compressive moduli, comparable to those of soft tissues like fat and muscle, indicating they may be suitable as soft tissue engineering scaffolds (72).

\subsection{Cell proliferation on foamed scaffolds}

In our studies we have utilized 3T3 mouse fibroblasts for initial cell proliferation studies as they are one of the major cellular components of mammalian skin tissue (73). The growth of cells on the foamed scaffolds was assessed using 3T3 fibroblasts and the Alamar Blue Assay. The fluorescent signal intensity (Figure 10) increased significantly over $72 \mathrm{~h}$, demonstrating an increase in the number of metabolically active cells present within the scaffolds. This indirect method of assessing cell viability shows that these scaffolds can support proliferation of 3T3 fibroblast cells.

To visualize whether cells can attach and survive on and inside the scaffolds, a live/dead stain was used. CellTracker ${ }^{\mathrm{TM}}$ dye is converted to its fluoreseent product by cellular esterases in live cells; the resulting red fluorescence signal from the cytoplasm indicates the presence of live cells (74). Figure 11 shows the distribution of 3T3 fibroblasts after three days of culture. In Figures 11 A \& B it can be seen that cells were located on the scaffold surfaces with some being clustered around the pore openings. Scaffolds (dimensions: diameter $5 \mathrm{~mm}$, height: $2 \mathrm{~mm}$ ) cut to reveal their centre (Figure $11 \mathrm{C} \& \mathrm{D}$ ) also show good distribution of the cells within the centre of the scaffolds. This suggests that cells have penetrated well within the interior of the scaffolds, providing further evidence that the scaffolds were interconnected, allowing penetration of the cells during seeding and/or subsequent cellular migration. Furthermore, the presence of live cells within the scaffolds suggests that there was sufficient oxygen and nutrient transport to and from the centre of the scaffolds to support this density of cells.

In Figure $11 \mathrm{E}$ the morphology of the $3 \mathrm{~T} 3$ fibroblast cells was evident. Most of the fibroblast cells in the scaffolds have a rounded morphology which is distinctly different from the flattened spread morphology typically observed on tissue culture plastic. This is consistent with previous observations that cells usually have a more rounded morphology in three dimensional structures, such as tissues and biomimetic hydrogel systems, compared to hard tissue culture plastic surfaces (75). Furthermore, the mechanical environment in the scaffolds was deliberately made to be soft, so cells could not generate large traction forces when they attach and pull against the surfaces. This results in a more rounded cell morphology, which more closely mimics the native morphology of fibroblast cells in soft human tissues.

\section{Conclusions}

Gas templating via turbulent mixing to generate foams in combination with TIPS was explored as a flexible and simple method for constructing macroporous hydrogel scaffolds which can be tailored for soft tissue engineering. A number of parameters which could affect foaming and 
bubble size distribution were investigated, from which manipulation of chitosan concentration was shown to exert the greatest effect on the overall porosity of the final scaffold. Chitosan hydrogels with up to $80 \%$ porosity and pore sizes between 80 and $170 \mu \mathrm{m}$ were successfully produced using this method. Large swelling ratios (1500\%-440\%) indicate that these foams can take up large volumes of liquid which can be beneficial for mass transport of nutrients and aid in rapid ingress of cells during cell seeding. The mechanical properties of these scaffolds showed low compressive moduli $(2.6-24 \mathrm{kPa})$, which strongly depend on their porosity and this in turns depends on the chitosan concentration. These scaffolds were shown to support fibroblast proliferation and therefore show promise as soft tissue engineering scaffolds.

\section{Acknowledgements}

The authors thank Benjamin Hibbs from the Advanced Fluorescence Imaging facility at the University of Melbourne for help with confocal imaging. We would also like to thank the Particulate Fluids Processing Centre (PFPC) for access to infrastructure and equipment. Dhee Biswas gratefully acknowledges the Australian Government for an Australian Postgraduate Award. P.A.T was recipient of the University of Melbourne's McKenzie fellowship and the Seed Funding from the Melbourne Materials Institute and The Bio21 Institute of Molecular Science and Biotechnology (Bio21) and now is a Vice Chancellor's Research Fellow at Queensland University of Technology. 


\section{Figure Captions:}

Figure 1: Schematic diagram of the four loop impeller mixing system used to create the foams showing (a) vertical and (b) horizontal cross sections (not to scale).

Figure 2: Schematic representation of the production of chitosan/PVA foamed hydrogel scaffolds

Figure 3: Effects of PVA concentration (chitosan concentration (CS): $25 \mathrm{mg} / \mathrm{ml}$, mixing speed (MS): $1500 \mathrm{rpm}$, foaming time (FT): $5 \mathrm{~min}$ ) (A); mixing speed (PVA: $20 \mathrm{mg} / \mathrm{ml}, \mathrm{CS}: 25 \mathrm{mg} / \mathrm{ml}$, FT: $5 \mathrm{~min}$ ) (B); foaming time (PVA: $20 \mathrm{mg} / \mathrm{ml}$, CS: $25 \mathrm{mg} / \mathrm{ml}$, MS: $1500 \mathrm{rpm}$ ) (C); and chitosan concentration (PVA: $20 \mathrm{mg} / \mathrm{ml}$, FT: $5 \mathrm{~min}$, MS: 1500rpm) (D) on the volume fraction of air entrained in the foams. $(n=3$, data $=$ average \pm standard deviation).

Figure 4: Effect of increasing chitosan concentration on the viscosity of the solution. PVA concentration: $20 \mathrm{mg} / \mathrm{ml}$; temperature: $25^{\circ} \mathrm{C}$.

Figure 5: Photographs of vials containing a) chitosan/PVA solution before and b) after foaming and c) the resulting solid foamed scaffold (diameter: $25 \mathrm{~mm}$ ).

Figure 6: Confocal micrographs of cross sections of scaffolds foamed with different surfactant concentrations A) $5 \mathrm{mg} / \mathrm{ml}$ PVA, B) $10 \mathrm{mg} / \mathrm{ml} \mathrm{PVA,} \mathrm{C)} 15 \mathrm{mg} / \mathrm{ml}$ PVA and D) $20 \mathrm{mg} / \mathrm{ml}$ PVA. CS: $25 \mathrm{mg} / \mathrm{ml}$, MS: $1500 \mathrm{rpm}$ and FT: $6 \mathrm{~min}$; Scale bars $200 \mu \mathrm{m}$.

Figure 7: Effect of (A) PVA concentration (MS: $1500 \mathrm{rpm}, \mathrm{CS}: 25 \mathrm{mg} / \mathrm{ml}, \mathrm{FT}: 6 \mathrm{~min}$ ), (B) mixing speed (CS: $25 \mathrm{mg} / \mathrm{ml}$, PVA: $20 \mathrm{mg} / \mathrm{ml}, \mathrm{FT}: 6 \mathrm{~min}$ ) and (C) chitosan concentration (PVA: $20 \mathrm{mg} / \mathrm{ml}$, MS: $1500 \mathrm{rpm}, \mathrm{FT}: 6 \mathrm{~min}$ ) on the pore sizes of chitosan/PVA scaffolds. $\mathrm{n}=100$ pores, data $=$ average \pm standard deviation, measured by the line counting method, error bars: \pm standard deviation. * Indicates statistically significant deviation of means ( $p<0.05$, ANOVA)

Figure 8: Effect of chitosan concentration on (A) porosities and (B) swelling ratios of chitosan/PVA scaffolds. Scaffold synthesis conditions PVA: $20 \mathrm{mg} / \mathrm{ml}$, mixing speed: $1500 \mathrm{rpm}$ and foaming time: 6 min, respectively. $\mathrm{n}=4$, data $=$ average \pm standard deviation. ${ }^{*}$ Indicates statistically significant deviation of means $(\mathrm{p}<0.05$, ANOVA)

Figure 9: Effect of chitosan concentration on compressive moduli of scaffolds. Scaffold synthesis conditions MS: $1500 \mathrm{rpm}$, PVA: $20 \mathrm{mg} / \mathrm{ml}, \mathrm{FT}: 6 \mathrm{~min}, \mathrm{n}=3$, data $=$ average \pm standard deviation $=$ standard deviation. * Indicates statistically significant deviation of means $(\mathrm{p}<0.05$, ANOVA)

Figure 10: 3 T3 mouse fibroblast proliferation shown on scaffolds over 3 days' incubation via an Alamar blue assay. Scaffold synthesis conditions CS: $30 \mathrm{mg} / \mathrm{ml}$, PVA: $20 \mathrm{mg} / \mathrm{ml}, \mathrm{MS}$ : $1500 \mathrm{rpm}$, FT: 6 min, $\mathrm{n}=4$, data $=$ average \pm standard deviation. ${ }^{*}$ Indicates statistically significant deviation of means $(\mathrm{p}<0.05$, ANOVA)

Figure 11: (A and B) confocal micrographs of the surface and (C, D \& E) within the centre of scaffolds after 3 days of culture with 3 T3 fibroblasts. Live cells' cytoplasms were tagged red with Celltracker ${ }^{\mathrm{TM}}$ deep red dye, nuclei stained blue with DAPI and scaffold walls visible by green fluorescence (due to GA mediated auto-fluorescence). (E) shows the rounded morphology 
of live 3T3 fibroblast cells. Scaffold synthesis conditions: CS: $30 \mathrm{mg} / \mathrm{ml}$, PVA: $20 \mathrm{mg} / \mathrm{ml}$, MS: $1500 \mathrm{rpm}, \mathrm{FT}: 6 \mathrm{~min}$.

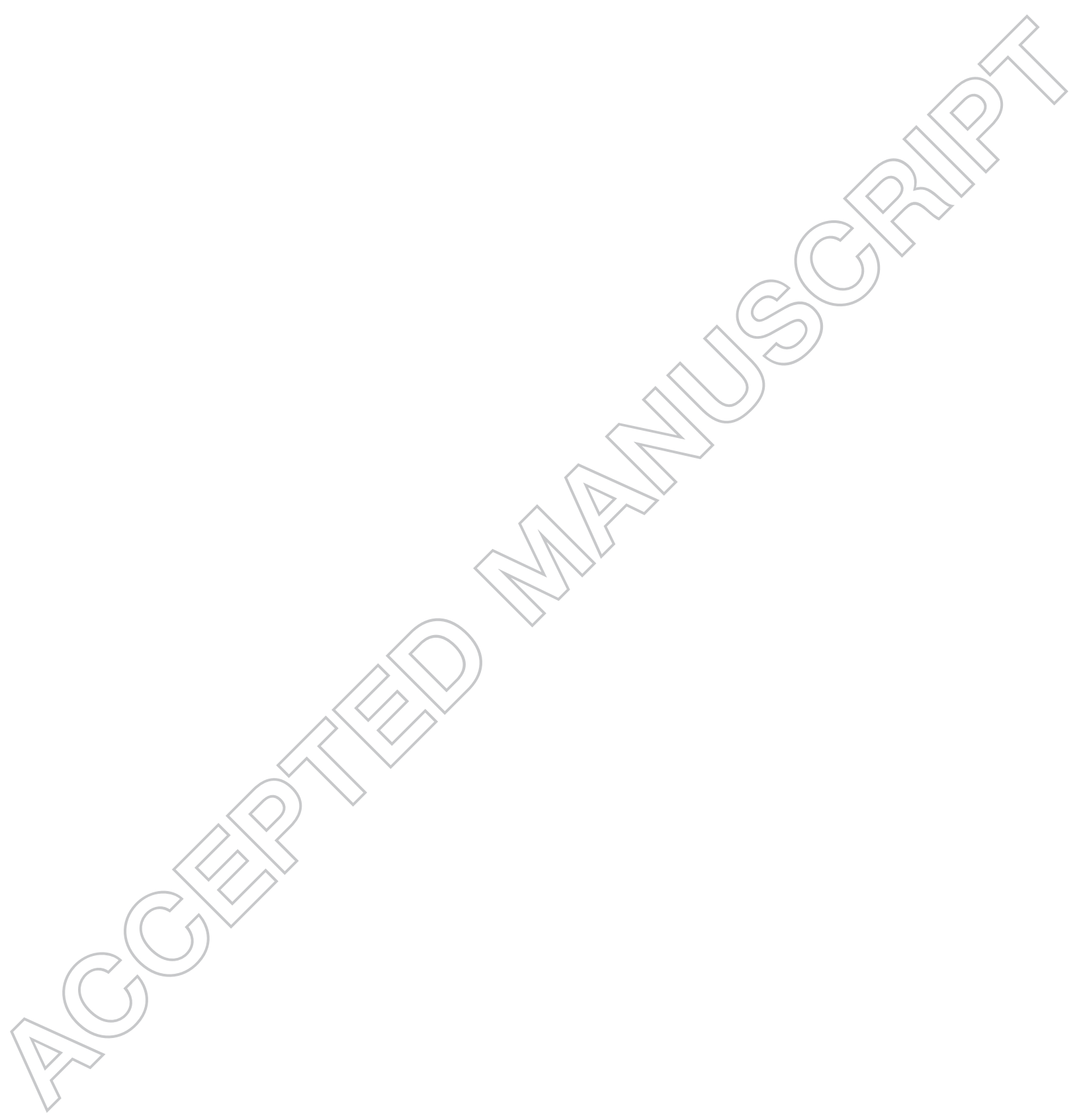


Table 1: Summary of parameters studied in foaming process

\begin{tabular}{lllll}
\hline $\begin{array}{l}\text { Foaming } \\
\text { parameters: }\end{array}$ & $\begin{array}{l}\text { Mixing speed } \\
(\mathrm{MS})(\mathrm{rpm})\end{array}$ & $\begin{array}{l}\text { PVA } \\
\text { concentration } \\
(\mathrm{mg} / \mathrm{ml})\end{array}$ & $\begin{array}{l}\text { Foaming time } \\
(\mathrm{FT})(\mathrm{min})\end{array}$ & $\begin{array}{l}\text { Chitosan } \\
\text { concentration } \\
\text { (CS) }(\mathrm{mg} / \mathrm{ml})\end{array}$ \\
\hline Test values & $600,800,1000$, & $0,1,3,5,10,15$, & $0.25,0.5,1,2,5,5,15,25,30,40$, \\
& $1200,1500,1800$, & 20,30 & 10 & 50 \\
& 2000 & & & \\
& & MS: $1500 \mathrm{rpm}$ & MS: $1500 \mathrm{rpm}$ & MS: $1500 \mathrm{rpm}$ \\
Test conditions & PVA: $20 \mathrm{mg} / \mathrm{ml}$ & FT: $5 \mathrm{~min}$. & PVA: $20 \mathrm{mg} / \mathrm{ml}$ & PVA: $20 \mathrm{mg} / \mathrm{ml}$ \\
& FT: $5 \mathrm{~min}$. & CS: $25 \mathrm{mg} / \mathrm{ml}$ & CS: $25 \mathrm{mg} / \mathrm{ml}$ & FT: $5 \mathrm{~min}$. \\
& CS: $25 \mathrm{mg} / \mathrm{ml}$ & & & \\
& & & &
\end{tabular}




\section{References:}

1. Ko J, Mohtaram NK, Ahmed F, Montgomery A, Carlson M, Lee PC, et al. Fabrication of poly ( $\epsilon$-caprolactone) microfiber scaffolds with varying topography and mechanical properties for stem cell-based tissue engineering applications. Journal of Biomaterials Science, Polymer Edition. 2014;25(1):1-17.

2. Stella JA, D'Amore A, Wagner WR, Sacks MS. On The Biomechanical Function Of Scaffolds For Engineering Load Bearing Soft Tissues. Acta biomaterialia. 2010;6(7):2365-81. doi: 10.1016/j.actbio.2010.01.001. PubMed PMID: PMC2878661.

3. Morais JM, Papadimitrakopoulos F, Burgess DJ. Biomaterials/Tissue Interactions: Possible Solutions to Overcome Foreign Body Response. The AAPS Journal. 2010;12(2):18896. doi: 10.1208/s12248-010-9175-3. PubMed PMID: PMC2844517.

4. Loh QL, Choong C. Three-dimensional scaffolds for tissue engineering applications: role of porosity and pore size. Tissue Engineering Part B: Reviews. 2013;19(6);485-502.

5. Collins MN, Birkinshaw C. Hyaluronic acid based scaffolds for tissue engineering-A review. Carbohydrate Polymers. 2013;92(2):1262-79. doi:

http://dx.doi.org/10.1016/j.carbpol.2012.10.028.

6. Sell S, Barnes C, Smith M, McClure M, Madurantakam P, Grant J, et al. Extracellular matrix regenerated: tissue engineering via electrospun biomimetic nanofibers. Polymer International. 2007;56(11):1349-60. doi: 10.1002/pi.2344.

7. Engler AJ, Sen S, Sweeney HL, Discher DE. Matrix Elasticity Directs Stem Cell Lineage Specification. Cell. 2006;126(4):677-89. doi: http://dx.doi.org/10.1016/j.cell.2006.06.044.

8. Hoffman AS. Hydrogels for biomedical applications. Advanced Drug Delivery Reviews. 2012;64, Supplement:18-23. doi: http://dx.doi.org/10.1016/j.addr.2012.09.010.

9. Malafaya PB, Silva GA, Reis RL. Natural-origin polymers as carriers and scaffolds for biomolecules and cell delivery in tissue engineering applications. Advanced Drug Delivery Reviews. 2007;59(4-5):207-33. doi: http://dx.doi.org/10.1016/j.addr.2007.03.012.

10. Boucard N, Viton C, Agay D, Mari E, Roger T, Chancerelle Y, et al. The use of physical hydrogels of chitosan for skin regeneration following third-degree burns. Biomaterials.

2007;28(24):3478-88. doi: http://dx.doi.org/10.1016/j.biomaterials.2007.04.021.

11. Arvanitoyannis IS, Kassaveti A. Fish industry waste: treatments, environmental impacts, current and potential uses. International Journal of Food Science \& Technology. 2008;43(4):72645. doi: $10.1111 /$ j.1365-2621.2006.01513.x.

12. Ravi Kumar MNV. A review of chitin and chitosan applications. Reactive and Functional Polymers. 2000;46(1):1-27. doi: http://dx.doi.org/10.1016/S1381-5148(00)00038-9.

13. Ueno H, Mori T, Fujinaga T. Topical formulations and wound healing applications of chitosan. Advanced Drug Delivery Reviews. 2001;52(2):105-15. doi: 10.1016/s0169409x(01)00189-2.

14. Ueno H, Yamada H, Tanaka I, Kaba N, Matsuura M, Okumura M, et al. Accelerating effects of chitosan for healing at early phase of experimental open wound in dogs. Biomaterials. 1999;20(15):1407-14. doi: 10.1016/s0142-9612(99)00046-0.

15. Ma L, Gao C, Mao Z, Zhou J, Shen J, Hu X, et al. Collagen/chitosan porous scaffolds with improved biostability for skin tissue engineering. Biomaterials. 2003;24(26):4833-41. doi: http://dx.doi.org/10.1016/S0142-9612(03)00374-0.

16. Li Z, Ramay HR, Hauch KD, Xiao D, Zhang M. Chitosan-alginate hybrid scaffolds for bone tissue engineering. Biomaterials. 2005;26(18):3919-28. doi:

10.1016/j.biomaterials.2004.09.062.

17. Zhang Y, Venugopal JR, El-Turki A, Ramakrishna S, Su B, Lim CT. Electrospun biomimetic nanocomposite nanofibers of hydroxyapatite/chitosan for bone tissue engineering. Biomaterials. 2008;29(32):4314-22. 
18. Tan H, Chu CR, Payne KA, Marra KG. Injectable in situ forming biodegradable chitosan-hyaluronic acid based hydrogels for cartilage tissue engineering. Biomaterials. 2009;30(13):2499-506.

19. Yamane S, Iwasaki N, Majima T, Funakoshi T, Masuko T, Harada K, et al. Feasibility of chitosan-based hyaluronic acid hybrid biomaterial for a novel scaffold in cartilage tissue engineering. Biomaterials. 2005;26(6):611-9.

20. Cooper A, Bhattarai N, Zhang M. Fabrication and cellular compatibility of aligned chitosan-PCL fibers for nerve tissue regeneration. Carbohydrate Polymers. 2011;85(1):149-56.

21. Gingras M, Paradis I, Berthod F. Nerve regeneration in a collagen-chitosan tissue- $>$ engineered skin transplanted on nude mice. Biomaterials. 2003;24(9):1653-61. doi:

http://dx.doi.org/10.1016/S0142-9612(02)00572-0.

22. Rafat M, Li F, Fagerholm P, Lagali NS, Watsky MA, Munger R, et al. PEG-stabilized carbodiimide crosslinked collagen-chitosan hydrogels for corneal tissue engineering. Biomaterials. 2008;29(29):3960-72.

23. Chen J, Li J, Xu Y, Huang Y, Ding H, Deng S, et al. Study on Biocompatibility of Complexes of Collagen-Chitosan-Sodium Hyaluronate and Cornea. Artificial organs.

2005;29(2):104-13.

24. Wang X, Li D, Wang W, Feng Q, Cui F, Xu Y, et al. Crosslinked collagen/chitosan matrix for artificial livers. Biomaterials. 2003;24(19):3213-20.

25. Lee SB, Kim YH, Chong MS, Hong SH, Lee YM, Study of gelatin-containing artificial skin V: fabrication of gelatin scaffolds using a salt-leaching method. Biomaterials. 2005;26(14):1961-8.

26. Cao Y, Mitchell G, Messina A, Price L, Thompson E, Penington A, et al. The influence of architecture on degradation and tissue ingrowth into three-dimensional poly(lactic-co-glycolic acid) scaffolds in vitro and in vivo. Biomaterials. 2006;27(14):2854-64. doi:

http://dx.doi.org/10.1016/j.biomaterials.2005.12.015.

27. Nam YS, Park TG. Biodegradable polymeric microcellular foams by modified thermally induced phase separation method. Biomaterials. 1999;20(19):1783-90.

28. Cao Y, Croll TI, O'Connor AJ, Stevens GW, Cooper-White JJ. Systematic selection of solvents for the fabrication of 3D combined macro-and microporous polymeric scaffolds for soft tissue engineering. Journal of Biomaterials Science, Polymer Edition. 2006;17(4):369-402.

29. Kolesky DB, Truby RL, Gladman A, Busbee TA, Homan KA, Lewis JA. 3D bioprinting of vascularized, heterogeneous cell-laden tissue constructs. Advanced materials.

2014;26(19):3124-30.

30. Annabi N, Mithieux SM, Weiss AS, Dehghani F. Cross-linked open-pore elastic

hydrogels based on tropoelastin, elastin and high pressure CO 2. Biomaterials. 2010;31(7):165565.

31. Annabi N, Fathi A, Mithieux SM, Martens P, Weiss AS, Dehghani F. The effect of elastin on chondrocyte adhesion and proliferation on poly ( $\varepsilon$-caprolactone)/elastin composites.

Biomaterials. 2011;32(6):1517-25. doi: http://dx.doi.org/10.1016/j.biomaterials.2010.10.024.

32. Ji C, Annabi N, Khademhosseini A, Dehghani F. Fabrication of porous chitosan scaffolds for soft tissue engineering using dense gas CO 2. Acta Biomaterialia. 2011;7(4):1653-64.

33. Keskar V, Marion NW, Mao JJ, Gemeinhart RA. In vitro evaluation of macroporous hydrogels to facilitate stem cell infiltration, growth, and mineralization. Tissue engineering Part A. 2009;15(7):1695-707.

34. Huh KM, Baek N, Park K. Enhanced swelling rate of poly (ethylene glycol)-grafted superporous hydrogels. Journal of bioactive and compatible polymers. 2005;20(3):231-43.

35. Barbetta A, Carrino A, Costantini M, Dentini M. Polysaccharide based scaffolds obtained by freezing the external phase of gas-in-liquid foams. Soft Matter. 2010;6(20):5213-24. 
36. Barbetta A, Rizzitelli G, Bedini R, Pecci R, Dentini M. Porous gelatin hydrogels by gasin-liquid foam templating. Soft Matter. 2010;6(8):1785-92.

37. Ross KA, Pyrak-Nolte LJ, Campanella OH. The effect of mixing conditions on the material properties of an agar gel - microstructural and macrostructural considerations. Food Hydrocolloids. 2006;20(1):79-87. doi: http://dx.doi.org/10.1016/j.foodhyd.2005.01.007.

38. Gibson L, Ashby M, Schajer G, Robertson C, editors. The mechanics of two-dimensional cellular materials. Proceedings of the Royal Society of London A: Mathematical, Physical and Engineering Sciences; 1982: The Royal Society.

39. Attenburrow G, Goodband R, Taylor L, Lillford P. Structure, mechanics and texture of a food sponge. Journal of Cereal Science. 1989;9(1):61IN1-70.

40. Hanselmann W, Windhab E. Flow characteristics and modelling of foam generation in a continuous rotor/stator mixer. Journal of Food engineering. 1998;38(4):393-405.

41. Jones JR, Hench LL. Effect of surfactant concentration and composition on the structure and properties of sol-gel-derived bioactive glass foam scaffolds for tissue engineering. Journal of Materials Science. 2003;38(18):3783-90. doi: 10.1023/A:1025988301542.

42. de Barros Coelho M, Magalhães Pereira M. Sol-gel synthesis of bioactive glass scaffolds for tissue engineering: effect of surfactant type and concentration. Journal of Biomedical

Materials Research Part B: Applied Biomaterials. 2005;75(2):451-6.

43. Chuanuwatanakul C, Tallon C, Dunstan DE, Franks GV. Controlling the microstructure of ceramic particle stabilized foams: influence of contact angle and particle aggregation. Soft Matter. 2011;7(24):11464-74.

44. Menon JU, Kona S, Wadajkar AS, Desai F, Vadla A, Nguyen KT. Effects of surfactants on the properties of PLGA nanoparticles. Journal of Biomedical Materials Research Part A. 2012;100A(8):1998-2005. doi: 10.1002/jbm.a.34040.

45. Savina IN, Dainiak M, Jungvid H, Mikhalovsky SV, Galaev IY. Biomimetic macroporous hydrogels: protein ligand distribution and cell response to the ligand architecture in the scaffold. Journal of Biomaterials Science, Polymer Edition. 2009;20(12):1781-95.

46. Henderson TM, Ladewig K, Haylock DN, McLean KM, O'Connor AJ. Cryogels for biomedical applications. Journal of Materials Chemistry B. 2013;1(21):2682-95.

47. Im O, Li J, Wang M, Zhang LG, Keidar M. Biomimetic three-dimensional nanocrystalline hydroxyapatite and magnetically synthesized single-walled carbon nanotube chitosan nanocomposite for bone regeneration. International Journal of Nanomedicine.

2012;7:2087-99. doi. 10.2147/IJN.S29743. PubMed PMID: PMC3356213.

48. Zhang Y, Zhang M. Synthesis and characterization of macroporous chitosan/calcium phosphate composite scaffolds for tissue engineering. Journal of biomedical materials research. 2001;55(3):304-12.

49. Bhat S, Kumar A. Cell proliferation on three-dimensional chitosan-agarose-gelatin cryogel scaffolds for tissue engineering applications. Journal of Bioscience and Bioengineering. 2012;114(6):663-70. doi: http://dx.doi.org/10.1016/j.jbiosc.2012.07.005.

50. O'Brien J, Wilson I, Orton T, Pognan F. Investigation of the Alamar Blue (resazurin) fluorescent dye for the assessment of mammalian cell cytotoxicity. European Journal of Biochemistry. 2000;267(17):5421-6.

51. Henderson TM, Ladewig K, Haylock DN, McLean KM, O'Connor AJ. Formation and characterisation of a modifiable soft macro-porous hyaluronic acid cryogel platform. Journal of Biomaterials Science, Polymer Edition. 2015;26(13):881-97.

52. Rosen M, Solash J. Factors affecting initial foam height in the Ross-Miles foam test. Journal of the American Oil Chemists' Society. 1969;46(8):399-402.

53. Morrison C, Schramm LL, Stasiuk EN. A dynamic foam method for the estimation of critical micelle concentrations at elevated temperatures and pressures. Journal of Petroleum Science and Engineering. 1996;15(1):91-100. 
54. Goette EK. Theoretical considerations of detergency. Journal of colloid science. 1949;4(5):459-84.

55. Lee MS, Kim J-C. Photo-responsive microspheres prepared using hydrophobically modified poly (vinyl alcohol)-coumarin conjugate. Colloid Journal. 2013;75(6):668-76.

56. Sawyerr F, Deglon D, O'Connor C. Prediction of bubble size distribution in mechanical flotation cells. Journal of the South African Institute of Mining and Metallurgy(South Africa). 1998;98(4):179-85.

57. Paul EL, Atiemo-Obeng V, Kresta SM. Handbook of industrial mixing: science and practice: John Wiley \& Sons; 2004.

58. Gonzenbach UT, Studart AR, Tervoort E, Gauckler LJ. Tailoring the Microstructure of Particle-Stabilized Wet Foams. Langmuir. 2006;23(3):1025-32. doi: 10.1021/la0624844.

59. Vijayaraghavan K, Nikolov A, Wasan D, Henderson D. Foamability of Liquid Particle Suspensions: A Modeling Study. Industrial \& Engineering Chemistry Research. 2009;48(17):8180-5. doi: 10.1021/ie801741q.

60. Gonzenbach UT, Studart AR, Tervoort E, Gauckler LJ. Stabilization of Foams with Inorganic Colloidal Particles. Langmuir. 2006;22(26):10983-8. doi: 10.1021/1a061825a.

61. Rohenkohl H, Kohlus R, Campbell G, Webb C, Pandiella S, Niranjan K. Foaming of ice cream and the time stability of its bubble size distribution. Bubbles in food. 1999:45-53.

62. Chang Y, Hartel RW. Stability of air cells in ice cream during hardening and storage. Journal of Food Engineering. 2002;55(1):59-70. doi: http://dx.doi,org/10.1016/S02608774(01)00242-4.

63. Monteiro Jr OAC, Airoldi C. Some studies of crosslinking chitosan-glutaraldehyde interaction in a homogeneous system. International Journal of Biological Macromolecules. 1999;26(2-3):119-28. doi: http://dx.doi.org/10.1016/S0141-8130(99)00068-9.

64. Costa-Júnior ES, Barbosa-Stancioli EF, Mansur AA, Vasconcelos WL, Mansur HS. Preparation and characterization of chitosan/poly (vinyl alcohol) chemically crosslinked blends for biomedical applications. Carbohydrate Polymers. 2009;76(3):472-81.

65. Ang TH, Sultana FSA, Hutmacher DW, Wong YS, Fuh JYH, Mo XM, et al. Fabrication of 3D chitosan-hydroxyapatite scaffolds using a robotic dispensing system. Materials Science and Engineering: C. 2002;20(1-2);35-42. doi: 10.1016/s0928-4931(02)00010-3.

66. Gobin AS, Froude VE, Mathur AB. Structural and mechanical characteristics of silk fibroin and chitosan blend scaffolds for tissue regeneration. Journal of Biomedical Materials Research Part A. 2005;74(3):465-73.

67. Chanda J, Kuribayashi R. Prevention of calcification and degeneration of biological tissue grafts for implantation in humans. Google Patents; 1997.

68. Jameela S, Misra A, Jayakrishnan A. Cross-linked chitosan microspheres as carriers for prolonged delivery of macromolecular drugs. Journal of Biomaterials Science, Polymer Edition. 1995;6(7):621-32.

69. Lanza R, Langer R, Vacanti JP. Principles of tissue engineering: Academic press; 2011. 70. Cook KLK, Hartel RW. Mechanisms of Ice Crystallization in Ice Cream Production. Comprehensive Reviews in Food Science and Food Safety. 2010;9(2):213-22. doi: 10.1111/j.1541-4337.2009.00101.x.

71. Tatterson GB. Fluid mixing and gas dispersion in agitated tanks: McGraw-Hill New York; 1991.

72. Discher DE, Janmey P, Wang Y-1. Tissue Cells Feel and Respond to the Stiffness of Their Substrate. Science. 2005;310(5751):1139-43. doi: 10.1126/science.1116995.

73. Pasparakis M, Haase I, Nestle FO. Mechanisms regulating skin immunity and inflammation. Nature Reviews Immunology. 2014;14(5):289-301. 
74. abcam. CytoPainter Cell Tracking Staining Kit - Deep Red Fluorescence (ab138894) 2015 [17/08/2015]. Available from: http://www.abcam.com/cytopainter-cell-tracking-stainingkit-deep-red-fluorescence-ab138894.html.

75. Hakkinen KM, Harunaga JS, Doyle AD, Yamada KM. Direct comparisons of the morphology, migration, cell adhesions, and actin cytoskeleton of fibroblasts in four different three-dimensional extracellular matrices. Tissue Engineering Part A. 2010;17(5-6):713-24. 
A

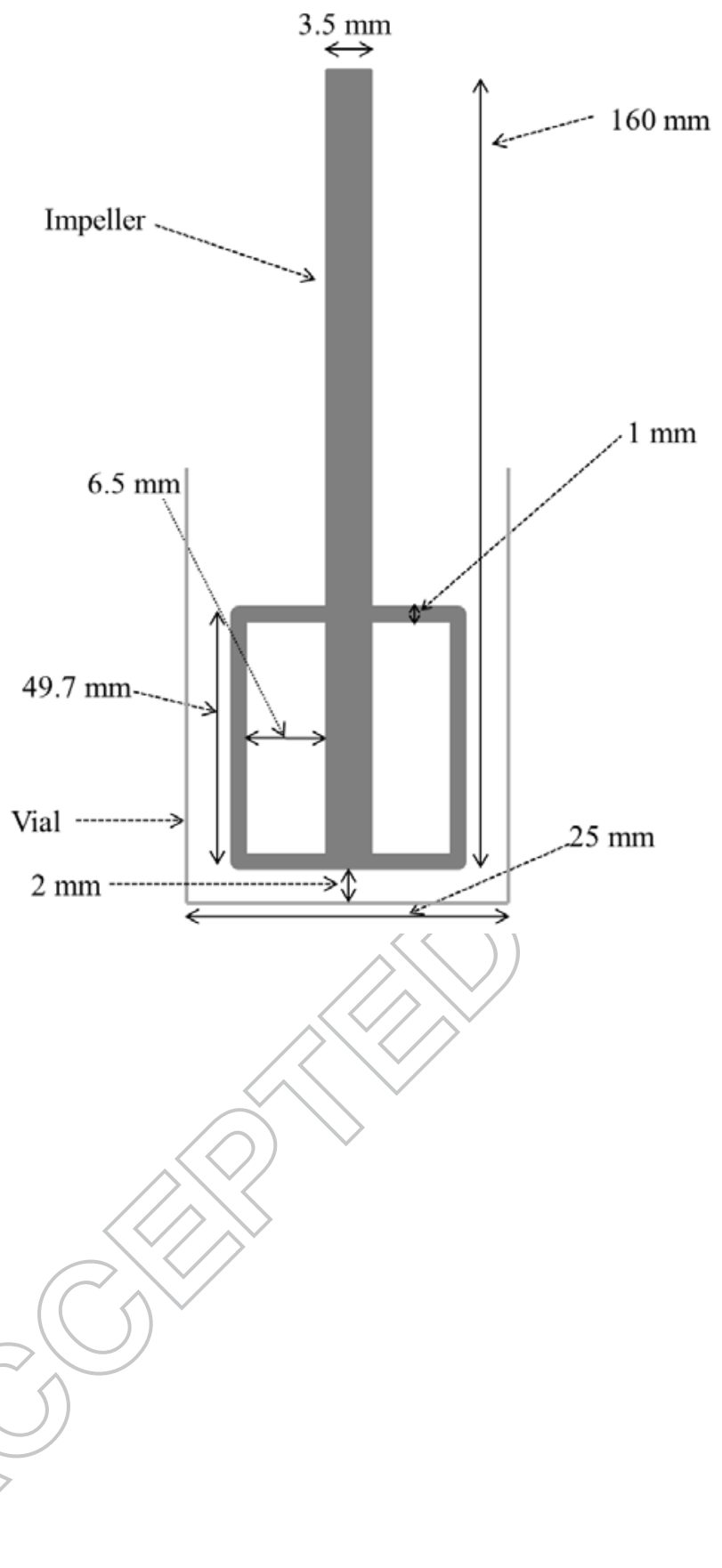




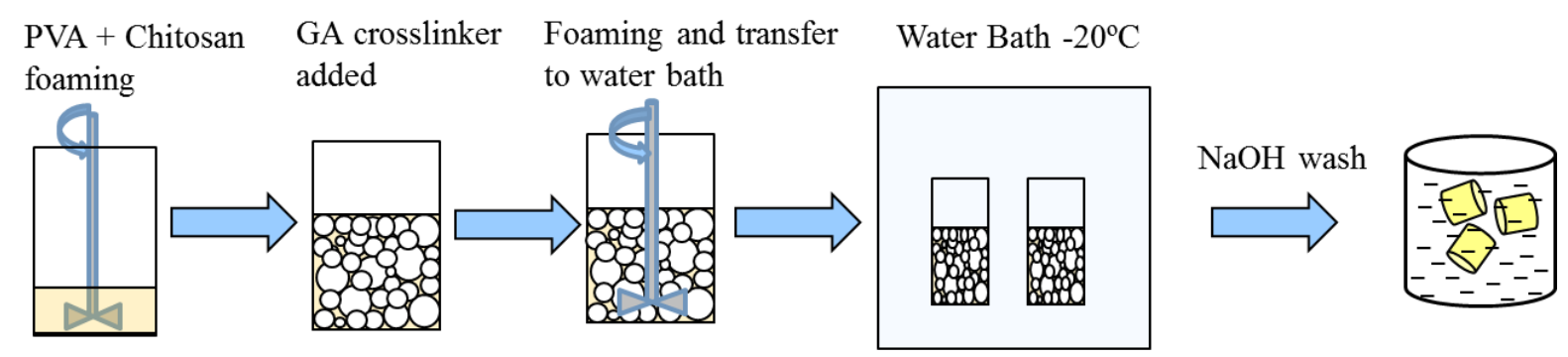

PBS wash, glycine wash

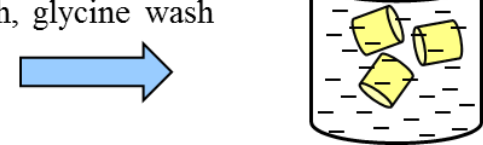

Foamed Chitosan Scaffold
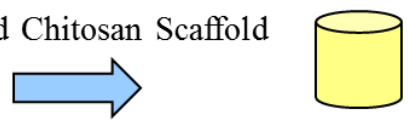

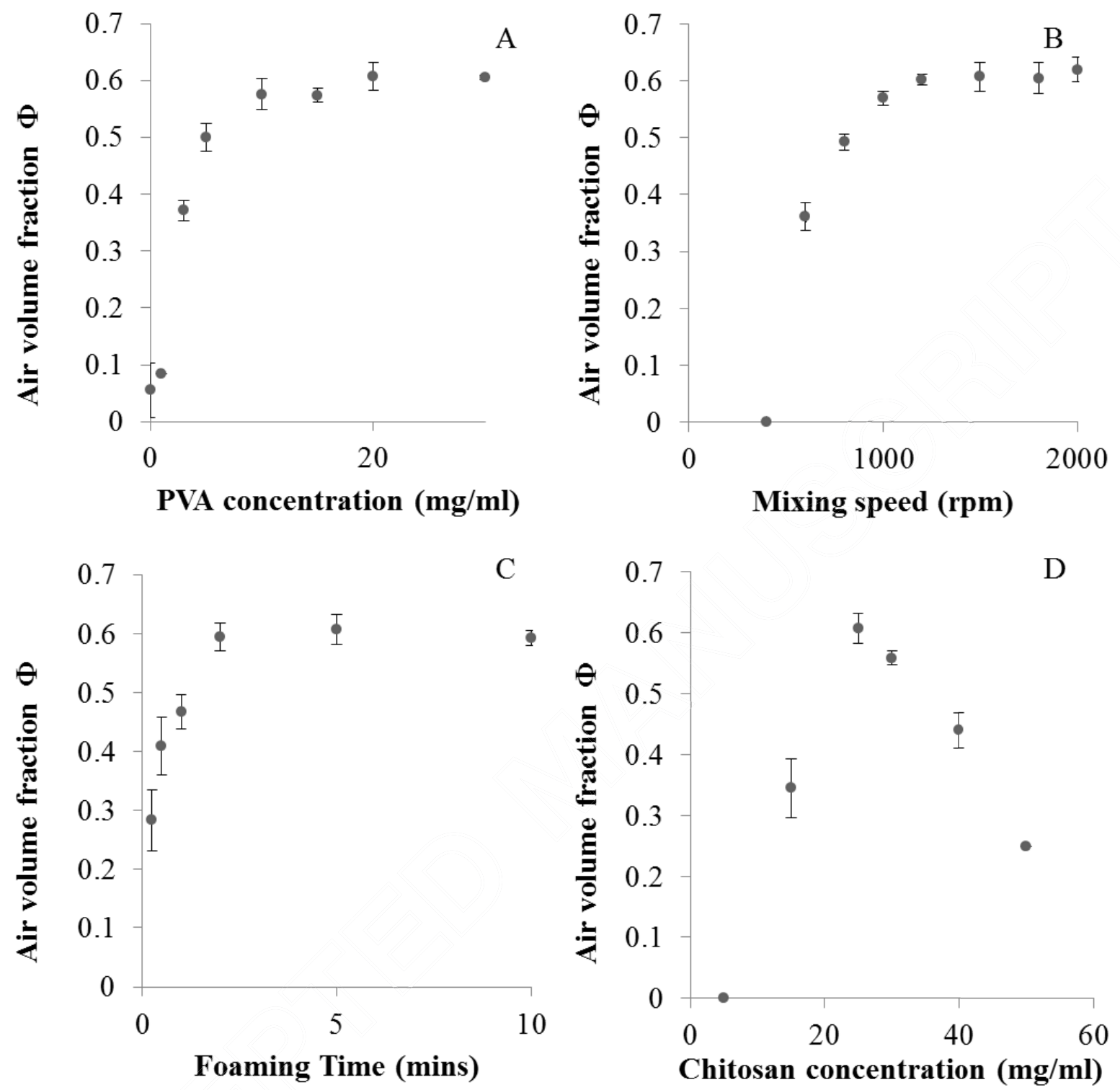


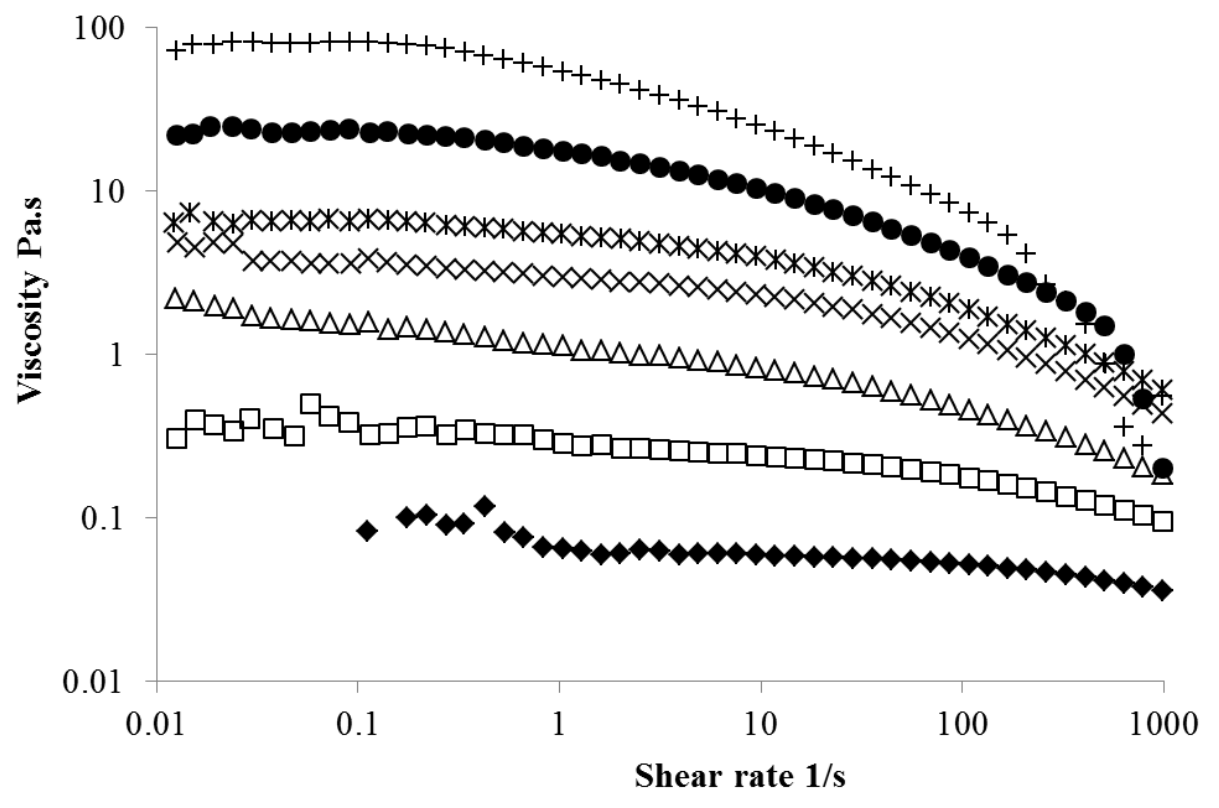

- $5 \mathrm{mg} / \mathrm{ml}$ Chitosan $\square 10 \mathrm{mg} / \mathrm{ml}$ Chitosan $\Delta 15 \mathrm{mg} / \mathrm{ml}$ Chitosan $\times 25 \mathrm{mg} / \mathrm{ml}$ Chitosan *30 mg/ml Chitosan - $40 \mathrm{mg} / \mathrm{ml}$ PVA $+50 \mathrm{mg} / \mathrm{ml}$ Chitosan Shear rate $1 /$ s 
A

Chitosan/PVA

solution

\section{B}

Foamed

solution
C

Foamed scaffold
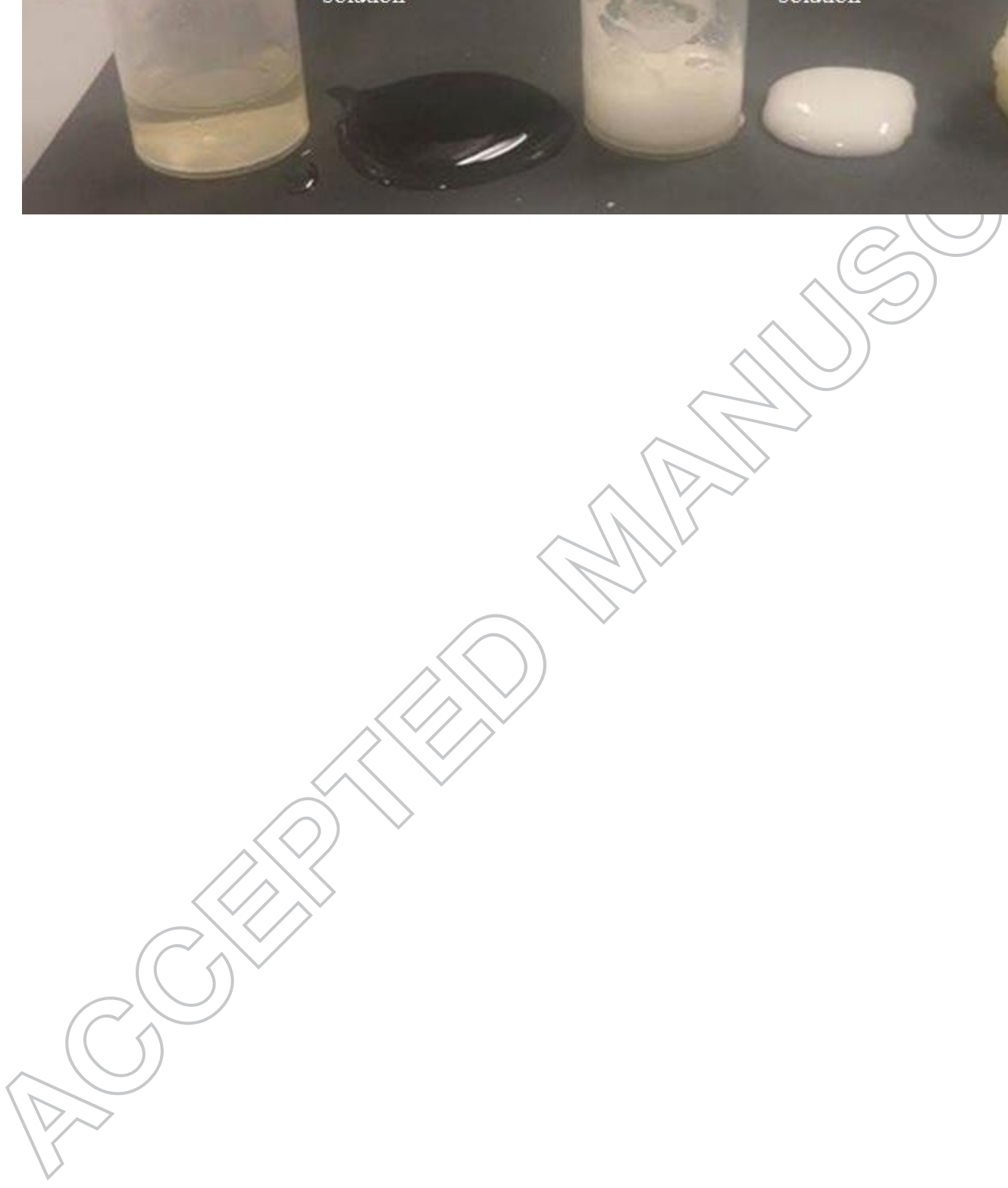


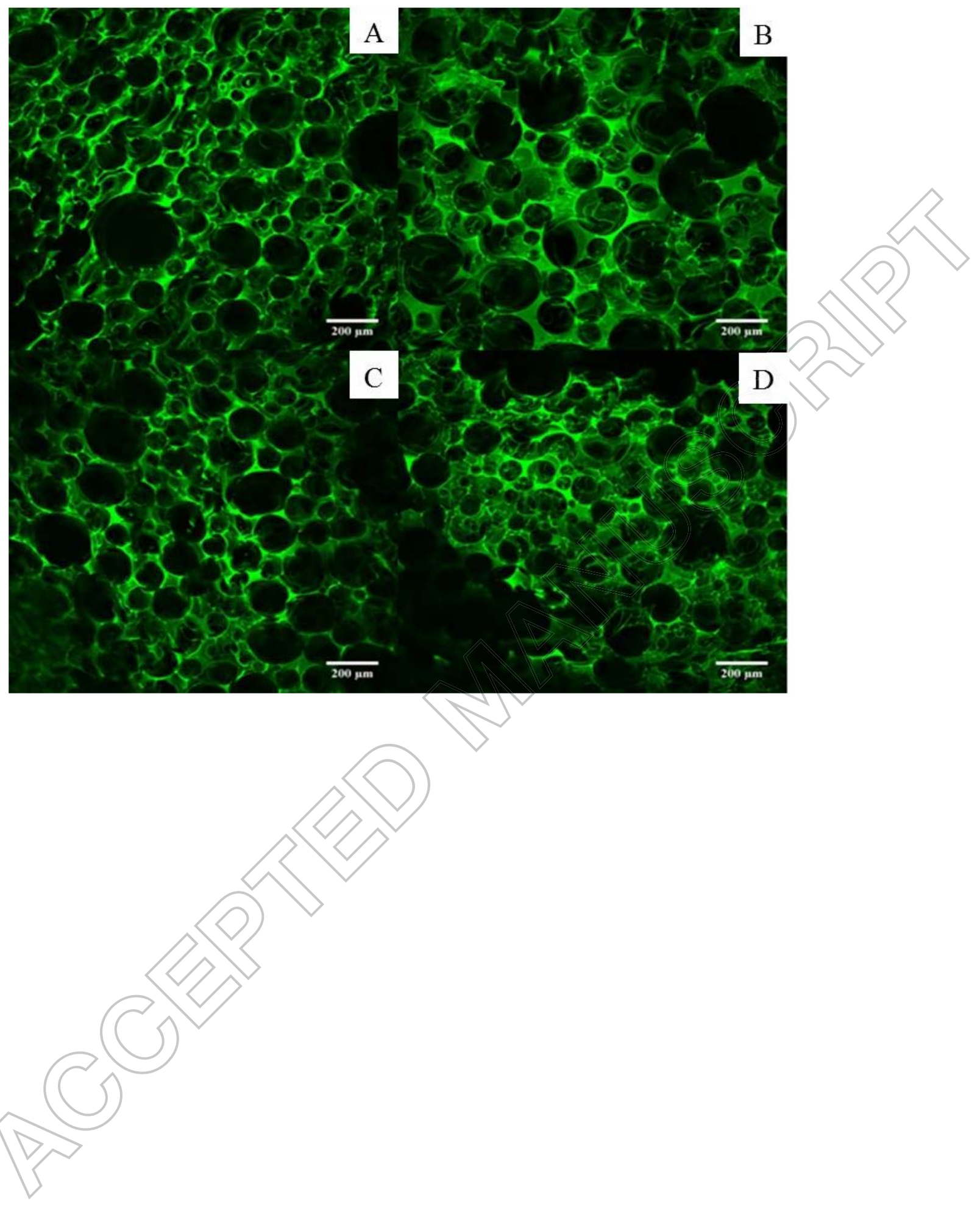




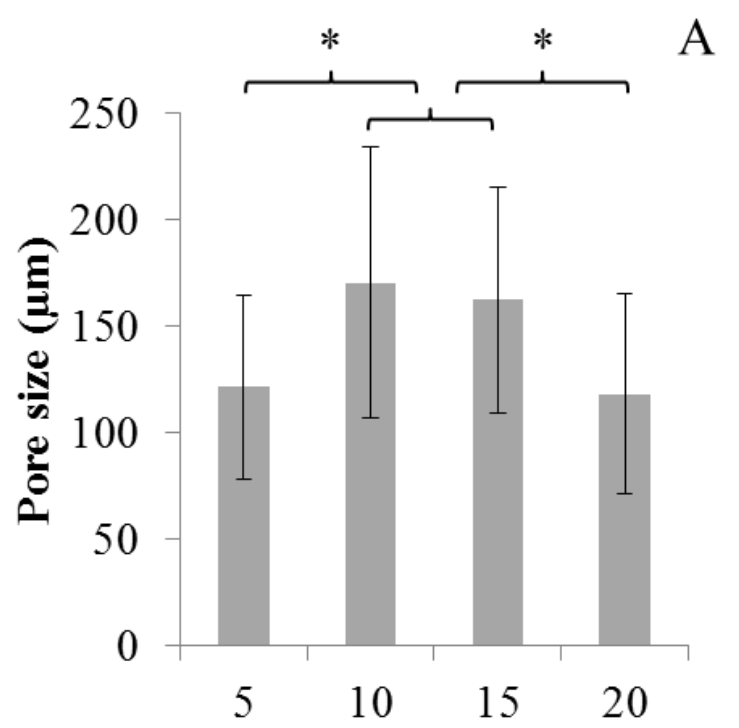

B

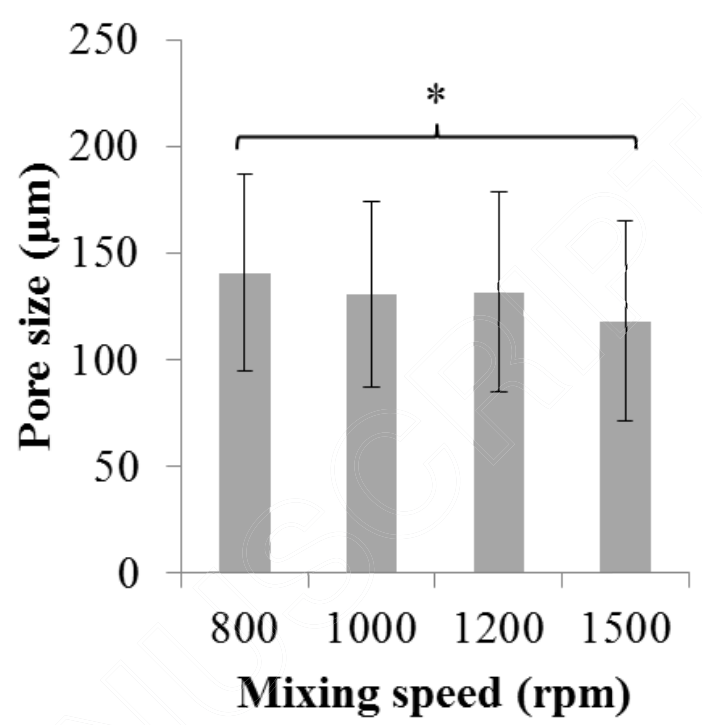

PVA concentration $(\mathrm{mg} / \mathrm{ml})$

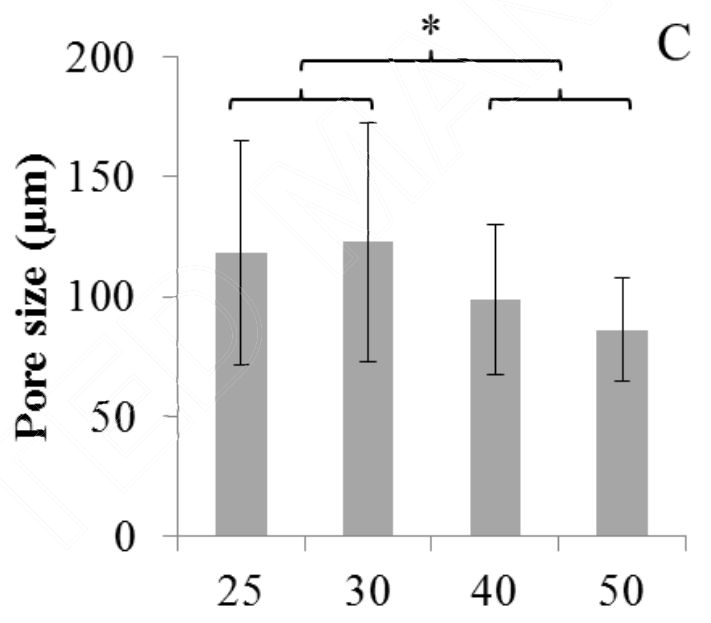

Chitosan concentration (mg/ml) 


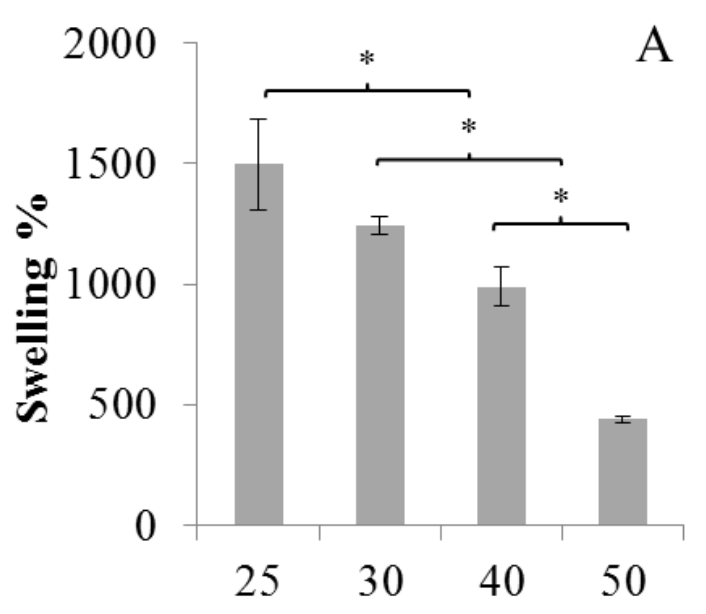

Chitosan concentration (mg/ml)

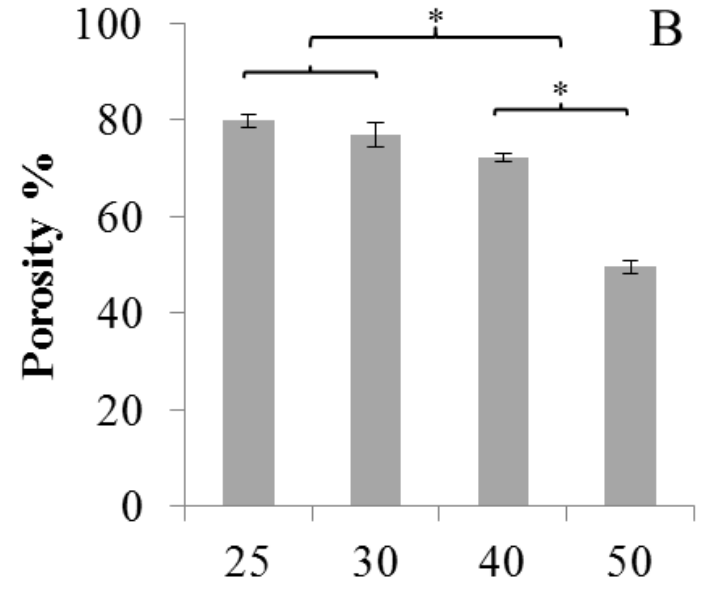

Chitosan concnetration (mg/ml) 


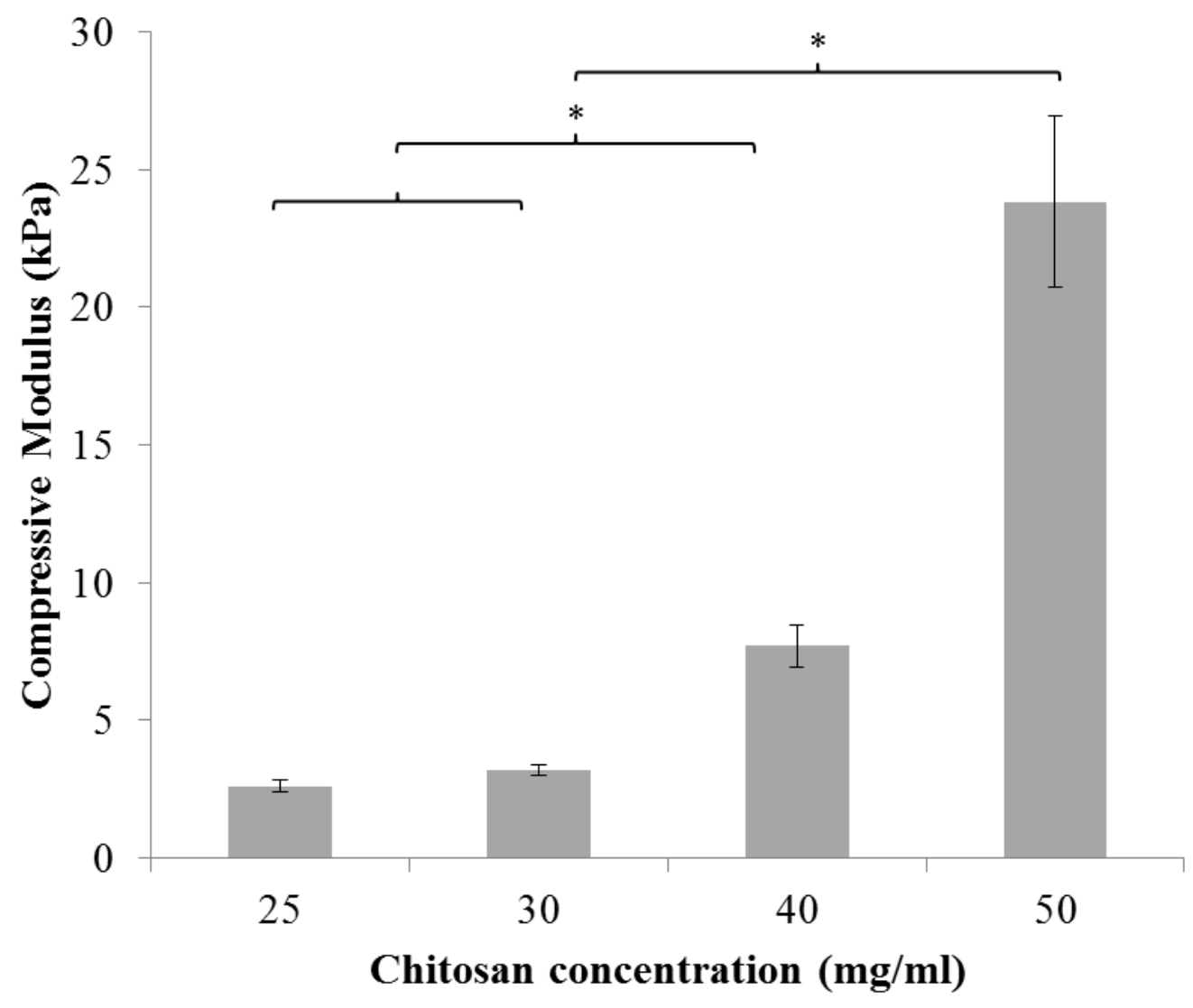



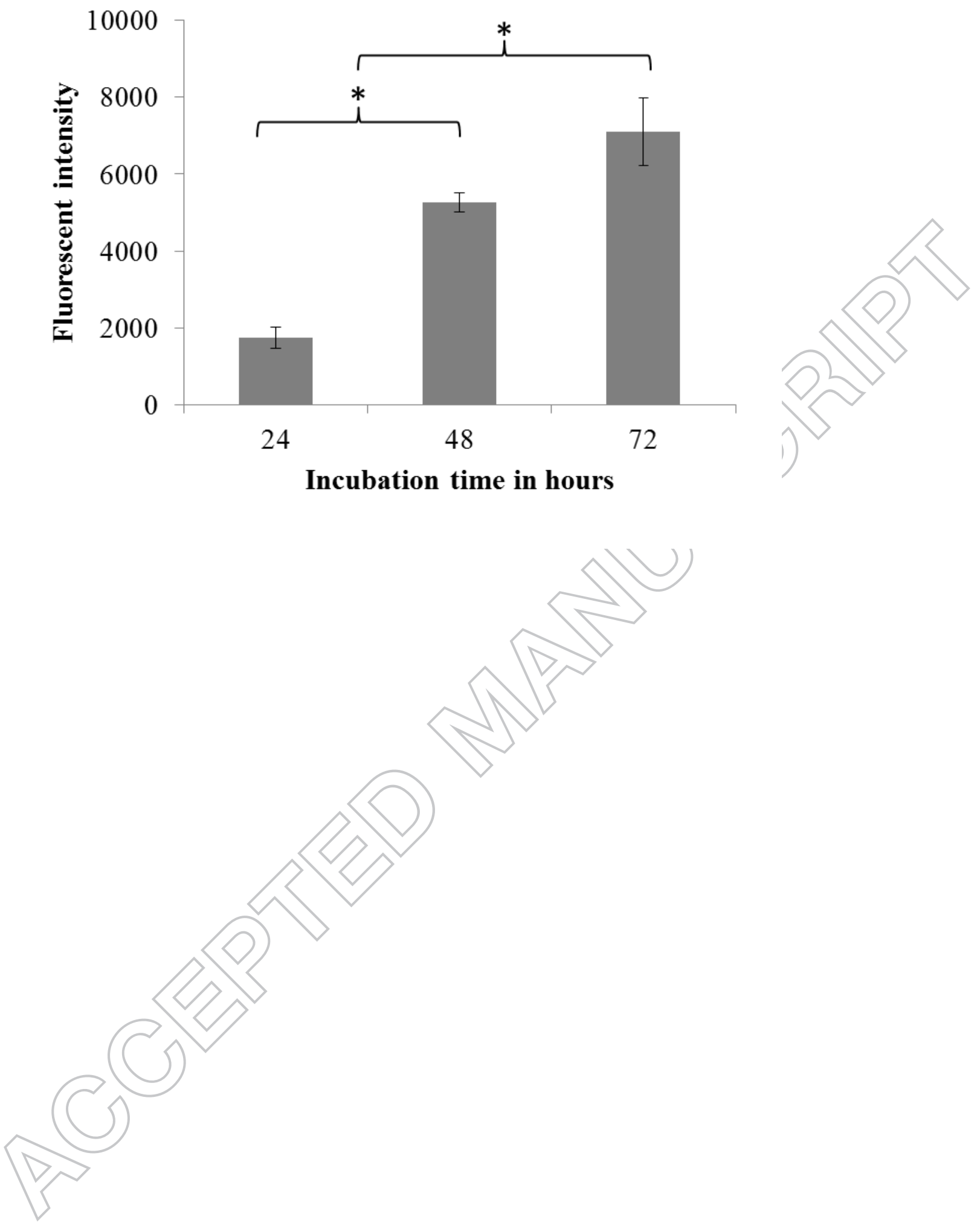

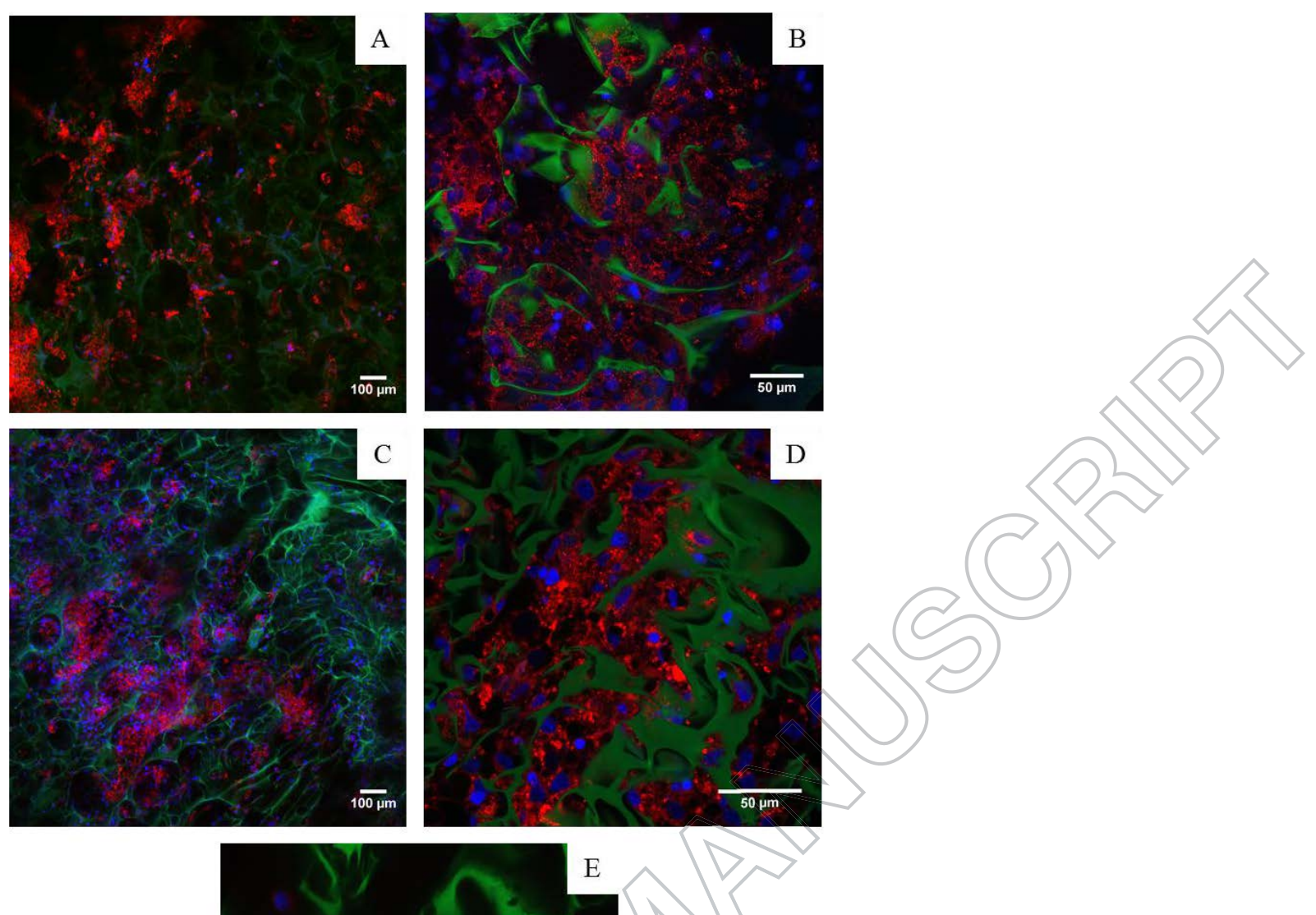

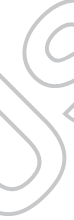

12 